\title{
Comparison of Misoprostol with Tranexamic Acid in Preventing Post- Partum Hemorrhage
}

MARYAM MATLOOB, ZILLE HYDER SYED, RUBINA QASIM, WAFA NAJEEB

Department of obstetrics and Gynecology, University Of Lahore, Mansoorah Teaching hospital.

Correspondence to Dr. Maryam Matloob, Senior Registrar, email: s_maryam@live.com, 03332688704

\begin{abstract}
Aim: To compare the amount of average blood loss in transamine and misoprostol groups in patients undergoing spontaneous vaginal delivery in third stage of labour.

Method: We conducted the randomized controlled trial from July $26^{\text {th }} 2016$ to $25^{\text {th }}$ of January 2017 .

Results: In my study the mean age of the patients undergoing normal vaginal delivery was 28.47 years, parity wise, $31 \%, 33 \%, 24 \%$ and $11 \%$ of participants were para 1, para 2, para 3 and para 4 respectively. Mean blood loss in group A was $224.08+/-20.81 \mathrm{mls}$ and in group B $331+/-398 \mathrm{mls}$.

Conclusion: This study has demonstrated that the blood loss in transamine group (group A) is less than the mean blood loss in misoprostol group (group B).

Keywords: Transamine, misoprostol, normal vaginal delivery.
\end{abstract}

\section{INTRODUCTION}

The postpartum hemorrhage (PPH) is the leading cause of maternal mortality ${ }^{1}$. The direct pregnancy-related maternal mortality rate in the United States is approximately 7-10 women per 100,000 live births. National statistics suggest that approximately $8 \%$ of these deaths are caused by $\mathrm{PPH}^{2}$. This is also the main cause of maternal deaths in Pakistan $^{3}$. According to World Health Organization statistics, $25 \%$ of maternal deaths are due to $\mathrm{PPH}$, accounting for more than 100,000 maternal deaths per year ${ }^{4}$. The American College of Obstetricians and Gynecologists shows that the estimate at 140,000 maternal deaths per year or 1 woman every 4 minutes $^{5}$.

The PPH is defined as the loss of more than $500 \mathrm{ml}$ of blood in vaginal delivery and greater than $1000 \mathrm{ml}$ in cesarean section ${ }^{6}$. Early or primary and late or secondary are defined as blood loss within and after 24 hours respectively. The etiological factors of the $\mathrm{PPH}$ are uterine atony, Retained placenta, Failure to progress during the second stage of labor, Placenta accreta, Instrumental delivery, Large-for-gestational age, and hypertensive disorders, Induction of labor and Augmentation of labor with oxytocin ${ }^{7}$.

Transamine (tranexamic acid) has a good role in reducing $\mathrm{PPH}$ loss ${ }^{8}$. Tranexamic acid is an anti-fibrinolytic agent that inhibits clot breakdown by blocking the lysine binding sites on plasminogen molecules ${ }^{8}$. Misoprostol is a synthetic prostaglandin E1 analogue which act as uterotonic agent and increases uterine contraction which results in decrease blood loss in postpartum period when given per rectal as compared to placebo $(p<0.0001)^{10}$. A systematic review showed one third decrease in PPH by the use of the tranexamic acid ${ }^{9}$. Another study showing that average blood loss between transamine and misoprostol group was $1.2+/-0.33$ liters and $1.18+/-0.47$ liters which is statistically not significant $(p=0.79)^{7}$. A study showed blood loss of $261.5+/-146.8 \mathrm{ml}$ and $349.97+/-188.35 \mathrm{ml}$ for transamine and without transamine groups respectively $(p=0.001)^{8}$.

Received on 24-0-2021
Accepted on 15-04-2021

The aim of the study is to determine the average amount of blood loss in liters between groups of transamine and misoprostol because there is only one trial in literature comparing the transamine with misoprostol. So this study is planned to generate confirmatory results that whether transamine should be used in routine for prevention of $\mathrm{PPH}$.

\section{MATERIALS AND METHODS}

We conducted this Randomized controlled trial in the department of obstetrics and gynecology, Shaikh zayed hospital, Lahore from July $26^{\text {th }} 2016$ to $25^{\text {th }}$ of January 2017.The sample size of 250 with 125 in each group is estimated by using $95 \%$ of confidence level, $80 \%$ power of test with expected blood loss of $349.97+/-188.35 \mathrm{ml}$ and $1180+/-470 \mathrm{ml}$ for transamine and without transamine groups respectively and the sampling technique was non probability consecutive sampling Inclusion criteria

- $\quad$ Female patients aged 17 to 45 years.

- $\quad$ Patients with term pregnancy i.e. 37 weeks and 6 days till 41 weeks and 6 days assessed by ultrasound and date of last menstrual period.

- Vertex presentation assessed by ultrasound

- Spontaneous delivery (as per operational definition ) Exclusion criteria

- Patient not willing to participate in study

- Patients with retained products of placenta assessed by ultrasound.

\section{RESULTS}

In this present study total 250 cases participated. The mean age of patients was 28.47 years with minimum age of 17 and maximum of 45 years (Table 1)Group wise distribution of parity among patients showed that $31 \%$, $33 \%, 24 \%$ and $11 \%$ patients were para 1 , para 2 , para 3 and para 4 respectively.(Table 2). Comparison of Mean blood loss between age groups of 20 to 32 years in group A and Group B was $222+/-81.46$ and 316+/- $20.64 \mathrm{mls}$ 
respectively with $\mathrm{p}$ value less than 0.0001 which is statistically significant and in age group 33 to 44 years in group A and Group B was $229+/-22.89$ and $324+/-26.9$ mls respectively with $p$ value less than 0.0001 which is statistically significant (Table 3).Comparison of mean blood loss according to parity in parity 1 group was $222+/-18 \mathrm{mls}$ and $316+/-20.46 \mathrm{mls}$ in group $A$ and $B$ respectively, in parity 2 group 222+/- $18.64 \mathrm{mls}$ and $316+/-20.64 \mathrm{mls}$ in group A and Group B respectively , in parity 3 group 229 $+/-22.89 \mathrm{mls}$ and $324+/-26.9 \mathrm{mls}$ in group $A$ and group $B$ respectively, inn parity 4 group $229+/-22.89$ mls and 324 $+/-26.9$ mls respectively with $p$ value of less than 0.0001 which is statistically significant (Table 4).

Table 1: Descriptive statistics of age (years)

\begin{tabular}{|l|c|c|c|}
\hline \multicolumn{2}{|l|}{ Groups } & $\begin{array}{c}\text { Group A } \\
\text { transamine }\end{array}$ & $\begin{array}{c}\text { Group B } \\
\text { misoprostol }\end{array}$ \\
\hline $\mathrm{N}$ & 250 & 125 & 125 \\
\hline Mean & 28.47 & 29.1 & 28.87 \\
\hline $\mathrm{SD}$ & 5.42 & 5.17 & 4.56 \\
\hline Minimum & 17 & 20 & 22 \\
\hline Maximum & 45 & 40 & 42 \\
\hline
\end{tabular}

Table 2: Group-wise distribution of parity

\begin{tabular}{|l|l|c|c|}
\hline \multicolumn{2}{|l|}{ Groups } & $\begin{array}{c}\text { Group A } \\
\text { transamine }\end{array}$ & $\begin{array}{c}\text { Group B } \\
\text { misoprostol }\end{array}$ \\
\hline $\mathrm{N}$ & 250 & 125 & 125 \\
\hline Mean & 28.47 & 29.1 & 28.87 \\
\hline $\mathrm{SD}$ & 5.42 & 5.17 & 4.56 \\
\hline Minimum & 17 & 20 & 22 \\
\hline Maximum & 45 & 40 & 42 \\
\hline
\end{tabular}

Table 3: Results of comparison of mean blood loss between group A (transamine) and Group B (misoprostol) with respect to age

\begin{tabular}{|l|l|c|c|c|}
\hline $\begin{array}{l}\text { Age group } \\
\text { (yrs) }\end{array}$ & Groups & \multicolumn{2}{|c|}{ Mean blood loss (mls) } & P-value \\
\cline { 2 - 4 } & & $\mathbf{n}$ & mean +/- SD & \\
\hline $20-32$ & $\mathrm{~A}$ & 62 & $222+/-18.46$ & $<0.0001$ \\
\cline { 2 - 4 } & $\mathrm{B}$ & 62 & $316+/-20.64$ & \\
\hline $33-42$ & $\mathrm{~A}$ & 63 & $229+/-22.89$ & $<0.0001$ \\
\cline { 2 - 4 } & $\mathrm{B}$ & 63 & $324+/-26.9$ & \\
\hline
\end{tabular}

Table 4: Comparison of mean blood loss according to parity Group A (Transamine) and Group B ( misoprostol ) with respect to parity

\begin{tabular}{|c|c|c|c|c|}
\hline \multirow[t]{2}{*}{ Parity } & \multirow[t]{2}{*}{ Groups } & \multicolumn{2}{|c|}{ Mean blood loss ( $\mathrm{mls}$ ) } & \multirow[t]{2}{*}{ p- value } \\
\hline & & $\mathbf{n}$ & mean +/- SD & \\
\hline \multirow[t]{2}{*}{1} & $\mathrm{~A}$ & 43 & $222+/-18$ & \multirow{2}{*}{$<0.0001$} \\
\hline & $\mathrm{B}$ & 43 & $316+/-2046$ & \\
\hline \multirow[t]{2}{*}{2} & $\mathrm{~A}$ & 37 & $222+/-22.86$ & \multirow[t]{2}{*}{$<0.0001$} \\
\hline & $\mathrm{B}$ & 37 & $316+/-2064$ & \\
\hline \multirow[t]{2}{*}{3} & $\mathrm{~A}$ & 28 & $229+/-22.89$ & \multirow[t]{2}{*}{$<0.0001$} \\
\hline & B & 30 & $324+/-26.90$ & \\
\hline \multirow[t]{2}{*}{4} & $\mathrm{~A}$ & 15 & $229+/-22.89$ & \multirow[t]{2}{*}{$<0.0001$} \\
\hline & $\mathrm{B}$ & 15 & $324+/-26.90$ & \\
\hline
\end{tabular}

\section{DISCUSSION}

This present randomized controlled trial was conducted at shaikh zayed hospital Lahore to determine the difference of mean blood loss among pregnant ladies undergoing normal vaginal delivery with transamine in Group and and misoprostol in group B.

In literature there are studies which showed Transamine (tranexamic acid) has a good role in reducing $\mathrm{PPH}$ loss $^{14}$. Tranexamic acid is an anti-fibrinolytic agent that inhibits clot breakdown by blocking the lysine binding sites on plasminogen molecules ${ }^{15}$. Misorostol is a synthetic prostaglandin E1 analogue which act as uterotonic agent and increases uterine contraction which results in decrease blood loss in postpartum period when given per rectlly as compared to placebo $(p<0.0001)^{16}$. A systematic review showed one third decrease in $\mathrm{PPH}$ by the use of the tranexamic acid ${ }^{17}$. Another study showing that average blood loss between transamine and misoprostol group was $1.2+/-0.33$ liters and $1.18+/-0.47$ liters which is statistically not significant $(p=0.79)^{18}$. A study showed blood loss of $261.5+/-146.8 \mathrm{ml}$ and $349.97+/-188.35 \mathrm{ml}$ for transamine and without transamine groups respectively $(p=0.001)^{19}$. The aim of this study was to determine the average amount of blood loss in mili liters between groups of transamine and misoprostol because there is only one trial in literature comparing the transamine with misoprostol. So this study is planned to generate confirmatory results that whether transamine should be used in routine for prevention of PPH.

\section{REFERENCES}

1. Khan KS, Wojdyla D, Say L, Gulmezoglu AM, Van Look PF. WHO analysis of the causes of maternal death: a systematic review. Lancet 2006; 367:1066-74

2. Berg CJ, Atrash HK, Koonin LM, Tucker M. Pregnancyrelated mortality in the United States, 1987-1990. Obstet Gynecol. Aug 1996;88(2):161-7.

3. Jaferey SN. Maternal Mortality in Pakistan compilation of available data. J Pak Med Assoc 2002; 52: 539-44

4. Abouzahr C. Antepartum and postpartum haemorrhage. In: Murray CJ, Lopez AD, eds. Health Dimensions of Sex and Reproduction. Boston, Mass: Harvard University Press; 1998:172-4.

5. American College of Obstetricians and Gynecologists. ACOG Practice Bulletin: Clinical Management Guidelines for Obstetrician-Gynecologists Number 76, October 2006: postpartum hemorrhage. Obstet Gynecol. Oct 2006;108(4):1039-47

6. Baskett TF. Complications of the third stage of labour. In: Essential Management of Obstetrical Emergencies. $3^{\text {rd }}$ ed. Bristol, England: Clinical Press; 1999:196-201

7. Sheiner E, Sarid L, Levy A, Seidman DS, Hallak M. Obstetric risk factors and outcome of pregnancies complicated with early postpartum hemorrhage: a population-based study. $J$ Matern Fetal Neonatal Med. Sep 2005;18(3):149-54

8. Yang $\mathrm{H}$, Zheng $\mathrm{S}$, Shi $\mathrm{C}$. Clinical study on efficacy of tranexamic acid in reducing postpartum blood loss: a randomized, comparative, multicenter trial. Zhonghua Fu Chan Ke ZAZhi 2001 oct;36(10):590-2

9. Okamoto S, Hijikata-Okunomiya A, Wanaka K, Okada $\mathrm{Y}$, Okamoto U. Enzyme controlling medicines: introduction. Semin Thromb Hemost 1997;23:493-501.

10. Derman $\mathrm{RJ}^{1}$, Kodkany BS, Goudar SS, Geller SE, Naik VA, Bellad MB, Patted SS, Patel A, Edlavitch SA, Hartwell T, Chakraborty $\mathrm{H}$, Moss $\mathrm{N}$. Oral misoprostol in preventing postpartum haemorrhage in resource-poor communities: a randomised controlled trial.Lancet. 2006 Oct 7;368(9543): 1248-53.

11. Henry DA, Carless PA, Moxey AJ, et al. Anti-fibrinolytic use for minimising perioperative allogeneic blood transfusion. Cochrane Database Syst Rev 2007;4:CD001886.

12. Sahhaf $F$, Abbasalizadeh $S$, Ghojazadeh $M$, Velayati $A$, Khandanloo R, Saleh P, Piri R, Naghavi-Behzad M. comparison effect of intravenous tranexamic acid and misoprostol for post partum haemorrhage.Niger Med J. 2014 Jul;55(4):348-53 
13. Gungorduk K, Asicioglu O, Yildirm G, Ark C, Tekridag Aj, Besimoglu B. Can intravenous injection of tranexamic acid be used in routine practice with active management of the third stage of labor in vaginal delivery? A randomized controlled study. Am J perinatal 2013;30(5):407-13.

14. Yang $H$, Zheng $S$, Shi C. Clinical study on efficacy of tranexamic acid in reducing postpartum blood loss: a randomized, comparative, multicenter trial. Zhonghua Fu Chan Ke ZAZhi 2001 oct;36(10):590-2

15. Okamoto S, Hijikata-Okunomiya A, Wanaka K, Okada Y, Okamoto U. Enzyme controlling medicines: introduction. Semin Thromb Hemost 1997;23:493-501.

16. Derman RJ ${ }^{1}$, Kodkany BS, Goudar SS, Geller SE, Naik VA, Bellad MB, Patted SS, Patel A, Edlavitch SA, Hartwell $\mathrm{T}$, Chakraborty $\mathrm{H}$, Moss $\mathrm{N}$. Oral misoprostol in preventing postpartum haemorrhage in resource-poor communities: a randomised controlled trial.Lancet. 2006 Oct 7;368(9543): 1248-53.

17. Henry DA, Carless PA, Moxey AJ, et al. Anti-fibrinolytic use for minimising perioperative allogeneic blood transfusion. Cochrane Database Syst Rev 2007;4:CD001886.

18. Sahhaf $F$, Abbasalizadeh $S$, Ghojazadeh $M$, Velayati A, Khandanloo R, Saleh P, Piri R, Naghavi-Behzad M. comparison effect of intravenous tranexamic acid and misoprostol for post partum haemorrhage. Niger Med J. 2014 Jul;55(4):348-53

19. Gungorduk K, Asicioglu O, Yildirm G, Ark C, Tekridag Aj, Besimoglu B. Can intravenous injection of tranexamic acid be used in routine practice with active management of the third stage of labor in vaginal delivery? A randomized controlled study. Am J perinatal 2013;30(5):407-13. 